\title{
REGULACJA NADZORU NAD RYNKIEM FINANSOWYM W UE - INTEGRACJA CZY DEZINTEGRACJA PRAWNYCH INSTRUMENTÓW ANTYKRYZYSOWYCH
}

\section{WSTĘP}

Dnia 1 stycznia 2011 r. weszła w życie nowa regulacja normująca nadzór nad rynkiem finansowym w Unii Europejskiej (UE) ${ }^{1}$. Jej powstanie stanowi odpowiedź europejskiego prawodawcy na problemy związane $z$ globalizacją usług finansowych na rynkach bankowym, giełdowym i ubezpieczeniowym w UE. Kryzys finansowy 2007-2009 stał się swoistym katalizatorem przemian legislacyjnych zarówno na szczeblu krajowym w państwach członkowskich UE, jak i w płaszczyźnie prawa europejskiego, które były zresztą szeroko dyskutowane w literaturze przedmiotu na długo przed wystąpieniem kryzysu². Wprowadzenie no-

1 Zob. rozporządzenie Parlamentu Europejskiego i Rady (UE) nr 1092/2010 z dnia 24.11.2010 r. $w$ sprawie unijnego nadzoru makroostrożnościowego nad systemem finansowym i ustanowienia Europejskiej Rady ds. Ryzyka Systemowego (Dz. Urz. UE L 331 z 15.12.2010 r., s. 1, dalej jako rozporządzenie o ERRS); rozporządzenie Parlamentu Europejskiego i Rady (UE) nr 1093/ 2010 z dnia 24.11.2010 r. w sprawie ustanowienia Europejskiego Urzędu Nadzoru (Europejskiego Urzędu Nadzoru Bankowego), zmiany decyzji nr 716/2009/WE oraz uchylenia decyzji Komisji 2009/78/WE (Dz. Urz. UE L 331 z 15.12.2010 r., s. 12, dalej jako rozporządzenie o EBA); rozporządzenie Parlamentu Europejskiego i Rady (UE) nr 1095/2010 z dnia 24.11.2010 r. w sprawie ustanowienia Europejskiego Urzędu Nadzoru (Europejskiego Urzędu Nadzoru Gietd i Papierów Wartościowych), zmiany decyzji nr 716/2009/WE i uchylenia decyzji Komisji 2009/77/WE (Dz. Urz. UE L 331 z 15.12.2010 r., s. 84, dalej jako rozporządzenie o ESMA); rozporządzenie Parlamentu Europejskiego i Rady (UE) nr 1094/2010 z dnia 24.11.2010 r. w sprawie ustanowienia Europejskiego Urzędu Nadzoru (Europejskiego Urzędu Nadzoru Ubezpieczeń i Pracowniczych Programów Emerytalnych), zmiany decyzji nr 716/2009/WE i uchylenia decyzji Komisji 2009/79/ /WE (Dz. Urz. UE L 331 z 15.12.2010 r., s. 48, dalej jako rozporządzenie o EIOPA).

2 Zob. np. A. Arora, The Global Financial Crisis: A New Global Regulatory Order?, „The Journal of Business Law" 2010, No. 8, s. 670; ibidem, The 2007-2009 banking crisis and the EU's regulatory response, „European Business Law Review” 2010, vol. 21, No. 5, October, s. 603 i n.; U. Denning, Zunehmende Konzentration der europäischen Finanzaufsicht, „Wirtschafts- 
wego europejskiego nadzoru finansowego jest wynikiem kompromisu zawartego między organami i instytucjami UE $z$ jednej strony, $z$ drugiej natomiast między państwami członkowskimi $\mathrm{UE}^{3}$.

Celem niniejszego opracowania jest analiza głównych założeń prawnych struktury nowego europejskiego nadzoru finansowego, a zwłaszcza antykryzysowych instrumentów oddziaływania na rynek finansowy UE przez organy tego nadzoru, ze szczególnym uwzględnieniem sektora bankowego ${ }^{4}$. Kryzys finansowy ujawnił luki w systemach nadzorczych państw UE i znaczne dysproporcje między krajową strukturą nadzorczą a europejską płaszczyzną aktywności na rynku finansowym w $\mathrm{UE}^{5}$. Przedmiotem szczególnego zainteresowania w artykule stała się próba udzielenia odpowiedzi na pytanie, czy nowe instrumenty prawne walki z kryzysem finansowym mogą w przyszłości przyczynić się do zwiększenia bezpieczeństwa i stabilności rynku finansowego w UE, czy zatem faktycznie następuje integracja na szczeblu europejskim prawnych instrumentów antykryzysowych.

Próba wstępnej i z pewnością cząstkowej oceny efektywności prawnych instrumentów oddziaływania organów nadzoru finansowego na rynek finansowy w UE została dokonana głównie na podstawie analizy formalnoprawnej unormowań europejskich. Zaznaczyć zarazem należy, że pełna ocena nowych uregulowań będzie możliwa dopiero w praktyce po określonym czasie funkcjonowania nowych struktur nadzoru finansowego. W dobie powiązania systemów prawnych, gospodarczych i finansowych konieczna jest integracja instrumentów antykryzysowych na szczeblu UE. Warto jednak również zastanowić się nad

dienst" 2001, vol. 81, No. 10, s. 595 i n.; G. Bertolozzo, The European Union facing the global arena: standard-setting bodies and financial regulation, „European Law Review” 2009, vol. 34, No. 2, s. 257; W. Pohl, Innovative Finanzinstrumente im gemeinsamen Europäischen Bankenmarkt, Baden-Baden 1994, s. 133 i n.; D. Masciandaro, Regulating the Regulators: The Changing Face of Financial Supervision Architectures before and after the Crisis, „European Company Law” 2009, vol. 6, No. 5, s. 187.

$\mathrm{Na}$ ten temat zob. zwłaszcza M. Lehmann, C. Manger-Nestler, Die Vorschläge zur neuen Architektur der europäischen Finanzaufsicht, „Europäische Zeitschrift für Wirtschaftsrecht“ 2010, Nr. 3, s. 87 i n.; G. Hofmann, Neue Finanzarchitektur, Reform der Aufsichtsregeln und Aufsichtspraktiken in Europa: Sind wir auf dem richtigen Weg?, „Kreditwesen” 2010, Nr. 13, s. 18 i n.; A. Schmitz, Finanzmarktkrise und Reorganisation von Banken, „Zeitschrift für Wirtschaftsrecht" 2010, Heft 24, s. 1203 i n.

$4 \mathrm{Na}$ temat nowego europejskiego nadzoru finansowego zob. zwłaszcza A. Jurkowska-Zeidler, Nowe europejskie ramy ochrony stabilności wewnętrznego rynku finansowego, [w:] System finansów publicznych. Prawo finansowe wobec wyzwań XXI wieku, red. A. Dobaczewska, E. Juchniewicz, T. Sowiński, wyd. I, Warszawa 2010, s. 195-204; M. Fedorowicz, Normatywne aspekty regulacji europejskiego nadzoru finansowego ze szczególnym uwzględnieniem europejskiego nadzoru w prawie bankowym, [w:] ibidem, s. 299-307; A. Michór, Nowa europejska architektura nadzoru nad rynkiem bankowym, „Bezpieczny Bank” 2011, nr 1, s. 71 i n.

5 Zob. dokument roboczy służb Komisji Europejskiej z 27.5.2009 r. SEK(2009) 716 uzupełniający Komunikat Komisji: „Europejski nadzór finansowy”. Podsumowanie oceny skutków, $\{\operatorname{KOM}(2009) 252$ wersja ostateczna $\}\{\operatorname{SEC}(2009) 715\}$, s. 2. 
potrzebą zapewnienia efektywności nowym instrumentom antykryzysowym. I w tym kontekście zaczynają się już pojawiać problemy prawne, tak w płaszczyźnie prawa UE, jak i płaszczyźnie prawa krajowego. Przykładem może być tutaj zwłaszcza umocowanie Europejskich Urzędów Nadzoru Finansowego (ESA) do wydawania indywidualnych decyzji adresowanych do instytucji finansowych oraz konsekwencje w prawie krajowym zastosowania „europejskich” indywidualnych decyzji przez ESA, posiadających pierwszeństwo przed decyzjami krajowych organów nadzoru. Wydaje się, że obecnie punkt ciężkości w dyskusji nad optymalnym kształtem sieci nadzorczej w obrębie rynku finansowego w UE powinien koncentrować się na zapewnieniu efektywności instrumentom prawnym w praktyce, co wiązać się powinno również ze zmianami w prawie krajowym. Wskazana problematyka stała się również przedmiotem rozważań w ramach niniejszego opracowania. W artykule przedstawiono rozróżnienie na antykryzysowe instrumenty prawne sensu stricto, jak i na systemowe instrumenty antykryzysowe sensu largo. Do pierwszej grupy zaliczyć należy instrumenty prawnego oddziaływania na rynek finansowy UE unormowane w aktach prawnych powołujących Europejski System Nadzoru Finansowego (ESNF), takie jak zalecenia, indywidualne decyzje, ostrzeżenia, wytyczne, wspólne i jednorodnie stosowane praktyki nadzorcze. Natomiast do drugiej grupy regulacji przyporządkować można unormowania proponujące wprowadzenie podatku bankowego, podwyższenie progów gwarantowanych wypłat deponentom, planów naprawczych, opracowywanie procedur mających zastosowanie w sytuacjach nadzwyczajnych i środków zapobiegawczych służących zminimalizowaniu systemowego znaczenia wszelkich przypadków upadłości, regulacje dotyczące europejskiego systemu gwarantowania depozytów, czy też m.in. europejskiego systemu postępowania naprawczego wobec banków.

Teza niniejszej publikacji koncentruje się wokół stwierdzenia, że globalizacja rynków finansowych spowodowała silną integrację instrumentów prawnych walki z kryzysem finansowym na szczeblu UE. Przy tym szczególne novum rozwiązań stanowią antykryzysowe instrumenty sensu stricto i sensu largo, które składają się na europejski swoisty system antykryzysowy. W ramach niniejszej publikacji podjęto również próbę dokonania oceny uregulowań analizowanych instrumentów.

\section{DWUFILAROWA STRUKTURA EUROPEJSKIEGO SYSTEMU NADZORU FINANSOWEGO}

Nową strukturę europejskiego nadzoru finansowego, zwaną Europejskim Systemem Nadzoru Finansowego, tworzą dwa filary: filar makroostrożnościowy oraz filar mikroostrożnościowy. Nooum wprowadzonej regulacji polega właśnie na tym, 
że na szczeblu europejskim informacja makroostrożnościowa kojarzona jest $\mathrm{z}$ informacją mikroostrożnościową ${ }^{6}$. W ramach filaru makroostrożnościowego utworzono Europejską Radę ds. Ryzyka Systemowego (ERRS). Z kolei nośnikiem filaru mikroostrożnościowego stały się 3 nowo powołane urzędy europejskiego nadzoru finansowego (tzw. ESA), do których należą Europejski Urząd Nadzoru Bankowego (EBA), Europejski Urząd Nadzoru Giełd i Papierów Wartościowych (ESMA) oraz Europejski Urząd Nadzoru Ubezpieczeń i Pracowniczych Programów Emerytalnych (EIOPA). Do głównych aktywności ERRS należy zwłaszcza sprawowanie nadzoru makroostrożnościowego nad systemem finansowym w UE. Celem działania ERRS jest przyczynianie się do przeciwdziałania ryzykom systemowym dla osiągnięcia stabilności finansowej w UE, a w ten sposób osiąganie sprawnego funkcjonowania rynku wewnętrznego. Szczególnie istotne są działania ERRS polegające na identyfikowaniu ryzyk systemowych i szeregowaniu ich pod względem ważności. Dla osiągnięcia celu stabilności finansowej ERRS posługuje się instrumentem ostrzeżenia w sytuacjach, gdy ryzyko systemowe jest uznawane za znaczące. Dla wymuszenia realizacji ostrzeżenia mogą być podawane do wiadomości publicznej.

Ponadto ERRS może również wydawać zalecenia w sprawie działań zaradczych w odniesieniu do zidentyfikowanego ryzyka i podawać je do wiadomości publicznej. Europejska Rada Ryzyka Systemowego jest uprawniona do monitorowania działań następczych w związku z ostrzeżeniami i zaleceniami. Ważnym zadaniem ERRS, z punktu widzenia tendencji globalizacyjnych i zapewnienia koordynacji w nadzorze finansowym, jest ścisła współpraca ze wszystkimi innymi stronami ESNF. Polega ona między innymi na udostępnianiu ESA informacji na temat ryzyk systemowych, które są potrzebne do realizacji ich zadań. Formalnym wyrazem tej współpracy jest opracowywanie, wspólnie z ESA, zestawu wskaźników ilościowych i jakościowych w celu określania i mierzenia ryzyka systemowego. Koordynacja nadzoru finansowego $\mathrm{w}$ aspekcie zewnętrznym polega natomiast na wspólpracy ERRS z międzynarodowymi instytucjami finansowymi, w szczególności z Międzynarodowym Funduszem Walutowym i Radą Stabilności Finansowej oraz z właściwymi organami w państwach trzecich w sprawach dotyczących nadzoru makroostrożnościowego. Warto jednak wskazać, że brak w regulacjach europejskich jakichkolwiek instrumentów wymuszających podjęcie tej współpracy czy choćby stworzenie gremium informującego się wzajemnie o występujących zagrożeniach na międzynarodowym rynku finansowym. Stąd efektywność tej wspólpracy uzależniona będzie w dużym stopniu od faktycznego podjęcia

6 Komunikat Komisji Europejskiej „Europejski nadzór finansowy” z 27.5.2009 r. KOM(2009) 252 wersja ostateczna, s. 4 i 5. 
aktywności i inicjowania dyskusji na forum międzynarodowym przez ERRS. $\mathrm{Z}$ tego punktu widzenia i w podanym zakresie uważać można, że integracja i konsolidacja praktyk nadzorczych oraz instrumentów nadzoru finansowego nie zostały dokonane w sposób wymuszający efektywność i optymalne wykorzystanie wprowadzonych struktur nadzorczych.

Z kolei ESA zajmują się głównie pozyskiwaniem informacji mikroostrożnościowej na rynku finansowym dla polepszenia funkcjonowania rynku wewnętrznego przez, po pierwsze, zapewnienie właściwego, skutecznego i spójnego poziomu regulacji i nadzoru; po drugie, wzmocnienie międzynarodowej koordynacji w zakresie nadzoru finansowego, oraz, po trzecie, zapewnienie właściwej regulacji oraz nadzoru w zakresie podejmowania ryzyka kredytowego i innych rodzajów ryzyka. Podstawową działalnością ESA jest przyczynianie się do ustanowienia wspólnych standardów i praktyk regulacyjnych i nadzorczych o wysokiej jakości, w szczególności przez przedstawianie opinii instytucjom UE oraz przez opracowywanie wytycznych, zaleceń i projektów regulacyjnych i wykonawczych standardów technicznych. Punkt ciężkości w aktywnościach ESA położono również na osiągnięcie celu spójnego stosowania prawa dotyczącego nadzoru nad rynkiem finansowym. Zadaniem ESA jest bowiem działalność ukierunkowana na osiągnięcie celu spójnego stosowania prawnie wiążących aktów unijnych, w szczególności przez budowanie wspólnej kultury nadzoru, zapewnianie spójnego, efektywnego i skutecznego stosowania prawa, zapobieganie arbitrażowi regulacyjnemu, mediację i rozstrzyganie sporów między właściwymi organami, zapewnianie skutecznego i spójnego nadzoru nad instytucjami finansowymi, zapewnianie spójności działań kolegiów organów nadzoru oraz podejmowanie działań m.in. w sytuacjach nadzwyczajnych. Dwufilarowość wprowadzonego systemu nadzoru finansowego w UE podkreślono przez uregulowanie obowiązku ściślej współpracy ESA z ERRS, w szczególności poprzez dostarczanie ERRS wszelkich informacji koniecznych do realizacji jej zadań oraz przez zapewnianie podejmowania odpowiednich działań następczych w związku z jej ostrzeżeniami i zaleceniami.

\section{ANTYKRYZYSOWE INSTRUMENTY PRAWNE SENSU STRICTO EUROPEJSKIEGO SYSTEMU NADZORU FINANSOWEGO}

Pod pojęciem antykryzysowych instrumentów sensu stricto ESNF rozumieć można funkcjonalnie powiązane ze sobą zespoły przepisów trzech nowych rozporządzeń o EBA, ESMA i EIOPA, które pozwalają bezpośrednio regulować działalność krajowych organów nadzorczych na rynkach finansowych w sytuacji połączenia 
i globalizacji tych rynków, a w szczególnych przypadkach bezpośrednio również aktywność instytucji finansowych na tym rynku?

Istotą analizowanego nadzoru $\mathrm{z}$ punktu widzenia możliwych form oddziaływania na rynek finansowy w UE jest kompetencja do korzystania $\mathrm{z}$ rozbudowanego instrumentarium prawnego, tworzącego wielopłaszczyznowy finansowy nadzór europejski w $\mathrm{UE}^{8}$. W przypadku ERRS chodzi o zalecenia, ostrzeżenia, publiczne zalecenia i ostrzeżenia oraz poufne ostrzeżenia. Warto podkreślić, że ERRS dla wymuszenia realizacji swoich zaleceń uwzględnionych w wymienionych aktach może podejmować działania następcze. Ich istotą jest wymuszenie posłuchu dla zaleceń przez wprowadzenie obowiązku udzielenia odpowiedzi na zalecenia, zarówno jeśli chodzi o podjęcie działań określonych w zaleceniu, jak i wyjaśnienie przyczyn zaniechania (art. 17 rozporządzenia o ERRS). W odniesieniu do ESA można wskazać, że mogą się one posługiwać wytycznymi, zaleceniami oraz indywidualnymi wiążącymi decyzjami kierowanymi bezpośrednio do organów nadzoru krajowego i wyjątkowo również do instytucji finansowych (art. 16-19 rozporządzenia o EBA, EIOPA i ESMA). Organy europejskiego nadzoru finansowego posługują się zatem instrumentami prawnymi, głównie o niewiążącym charakterze. Warto jednak podkreślić, że nie oznacza to jeszcze, że ich akty nie znajdą szerokiego zastosowania wśród podmiotów rynku finansowego w UE.

Jedną z możliwości efektywnego zapewnienia realizacji dla niewiążących instrumentów organów nadzoru może stać się aktywność porównywalna do Komitetu Bazylejskiego. W tym przypadku niewiążące instrumenty Komitetu w postaci zaleceń są implementowane do dyrektyw państw członkowskich UE. Być może podobna aktywność zostanie przejęta przez organy ESNF. Wówczas niewiążące zalecenia, ostrzeżenia i wytyczne, których treść zostałaby implementowana do krajowych porządków prawnych państw UE, wpływałyby integrująco na działania podmiotów rynku finansowego w UE. Do tego celu potrzebna byłaby jednak zintensyfikowana współpraca między ESNF a prawodawcą europejskim, przy akceptacji państw członkowskich. Jak pokazują działania Komitetu Bazylejskiego9 często jego zalecenia były wdrażane do krajowych porządków prawnych, a sam

\footnotetext{
Z uwagi na ramy niniejszego opracowania przedmiotem rozważań stały się wyłącznie prawne instrumenty walki z kryzysem finansowym w sektorze bankowym w płaszczyźnie prawa UE. Na temat krajowych instrumentów antykryzysowych zob. ustawa z dnia 12 lutego 2009 r. o udzielaniu przez Skarb Państwa wsparcia instytucjom finansowym (DzU 2009 r., Nr 39, poz. 308). Odnośnie do antykryzysowego pakietu niemieckiego zob. M. Fedorowicz, Podstawowe zatożenia niemieckiego pakietu ustaw o stabilizacji rynku finansowego z dnia 17.10.2008 r., „EuroEkspert” 2009, nr 1, passim.

8 Por. M. Lamandini, When More is Needed: The European Financial Supervisory Reform and Its Legal Basis, „European Company Law” 2009, vol. 6, No. 5, s. 198.

9 Zob. zwłaszcza J. Zombirt, Nowa umowa kapitałowa ewolucja czy rewolucja, Warszawa 2007, passim; M. Iwanicz-Drozdowska, Bazylea II $i$ wyplacalność - szanse i wyzwania, [w:] Bankowość, red. J. Węcławski, Lublin 2006, ss. 138-145.
} 
Komitet darzony jest znacznym autorytetem, mimo że jego słabością jest niewielkie zainteresowanie ryzykiem płynności ${ }^{10}$. $\mathrm{Na}$ marginesie warto podkreślić, że obecnie trwają prace nad wdrożeniem pakietu Basel III do krajowych porządków prawnych państw członkowskich $\mathrm{UE}^{11}$. Warto również podkreślić, że w zakresie nadzoru nad segmentem bankowym rynku finansowego zapewnić należy także współpracę między ESNF a Komitetem Bazylejskim.

O efektywności instrumentów antykryzysowych świadczyć będzie wiele czynników. Do najistotniejszych zaliczyć należy: po pierwsze, jakościowe określenie zaleceń i wytycznych. Chodzi o to, żeby materialna treść aktów organów ESNF gwarantowała wysoki poziom i bezpieczeństwo zachowań na rynku finansowym w UE. W tym kontekście pewien niepokój budzi fakt, że tytułem przykładu stress testy, którym banki zostały poddane przez EBA, okazały się instrumentem, który zaniżał dotychczasowe wymogi stawiane bankom ${ }^{12}$. Po drugie, efektywność instrumentów antykryzysowych uzależniona jest w znacznym stopniu od szybkości i bezpieczeństwa przepływu informacji mikroostrożnościowej generowanej na poziomie instytucji finansowej, a następnie na poziomie nadzorców krajowych, która ma finalnie trafiać na poziom europejski przez działalność ESA do ERRS. Tymczasem dopiero $\mathrm{w}$ chwili obecnej uregulowano w Polsce częściowo przestrzeganie obowiązków informacyjnych, wynikających z unormowań dotyczących nadzoru finansowego ${ }^{13}$. Działalność ERRS jest w dużym stopniu uzależniona od stałego dopływu informacji makroostrożnościowej ze strony banków centralnych i zwłaszcza ESBC. Za priorytetowe uznać obecnie należy zapewnienie szybkiego, bezpiecznego transferu danych makroekonomicznych. Zresztą akurat w przypadku informacji makroostrożnościowej ryzyko niekompletnych, nieterminowo

10 O ryzyku płynności i działalności Komitetu Bazylejskiego zob. K. Marcinkowska, Kręte ścieżki Bazylei..., czyli standardy kapitałowe banków: wczoraj, dziś i jutro, „Annales Universitatis Mariae Curie-Skłodowska", Lublin-Polonia 2010, XLIV, 2, Sectio H, s. 55 i n., a także eadem, Standardy kapitałowe banków, Bazylejska Nowa Umowa Kapitałowa w polskich regulacjach nadzorczych, Gdańsk 2009, passim.

${ }_{11}$ Zob. zwłaszcza E. Rutkowska-Tomaszewska, Zasady racjonalnego zarzadzania ryzykiem płynności banków w zaleceniach Komitetu Bazylejskiego, [w:] Wyzwania regulacyjne wobec doświadczeń globalnego kryzysu finansowego, red. J. Szambelańczyk, Warszawa 2011, s. 148 i n. oraz P. Stanisławiszyn, Perspektywy zmian europejskich regulacji w zakresie nadzoru finansowego w 2011 r., [w:] ibidem, s. 131 i n.

12 „Rzeczpospolita” z 10 marca 2011 r. dodatek ekonomiczny, Testy dla banków okazały się tagodniejsze.

13 Zob. rozwiązania ustawy z dnia 28 kwietnia 2011 r. o zmianie ustawy - Prawo bankowe, ustawy o obrocie instrumentami finansowymi oraz ustawy o nadzorze nad rynkiem finansowym (DzU Nr 131, poz. 763), dalej jako ustawa implementująca CRD II. W ustawie przewidziano m.in., że Komisja Nadzoru Finansowego informuje EBA, ESMA i EIOPA o działaniach kolegiów, w szczególności o sytuacjach nadzwyczajnych, oraz przekazuje informacje, które są szczególnie istotne dla konwergencji praktyk nadzorczych (art. 1 pkt 13 oraz art. 2 pkt 12e ustawy implementującej CRD II). 
przekazywanych czy w ogóle braku danych, jest nikłe, gdyż w skład ERRS wchodzą przedstawiciele zarówno narodowej, jak i europejskiej bankowości centralnej. Po trzecie, realność stosowania instrumentów antykryzysowych łączona być musi $z$ realizacją ewentualnych indywidualnych wiążących decyzji adresowanych do krajowych nadzorców lub bezpośrednio do instytucji finansowych. W tej grupie problemów warto zwrócić uwagę na - jak się wydaje - niekompletność podstaw prawnych określonych w prawie UE, jak i zwłaszcza w prawie polskim - na gruncie ustawy - Kodeks postępowania administracyjnego ${ }^{14}$ i ustawy o nadzorze nad rynkiem finansowym ${ }^{15}$.

\section{ANTYKRYZYSOWE INSTRUMENTY SYSTEMOWE SENSU LARGO RYNKU FINANSOWEGO W UE}

Do antykryzysowych instrumentów systemowych rynku finansowego w UE (instrumentów antykryzysowych sensu largo) można zaliczyć m.in. projekt unormowania dotyczący podatku bankowego, regulacje systemu gwarantowania depozytów w UE, unormowania w przypadku upadłości banków, materie implementowane w ramach dyrektywy CRD II, jak i działalność Komitetu Bazylejskiego.

Wśród ostatnich pomysłów na złagodzenie skutków przyszłego, ewentualnego kryzysu finansowego wspomnieć należy dyskutowane wprowadzenie podatku bankowego ${ }^{16}$. Jego celem byłoby zasilenie specjalnego funduszu (stabilności finansowej) wsparcia sektora finansowego w razie wystąpienia sytuacji kryzysowej. Jednym z uzasadnień dla wprowadzenia podatku od niektórych instytucji finansowych (w tym i banków) jest potrzeba eliminacji finansowania przez sektor publiczny działań pomocowych $\mathrm{w}$ razie wystąpienia problemów z płynnością w czasie kryzysu finansowego ${ }^{17}$. Pomysł ten miałby stanowić realizację unijnej konstrukcji stworzenia funduszu restrukturyzacyjnego finansowanego właśnie przez instytucje finansowe ${ }^{18}$. Kryzys finansowy wymusił również na państwach UE, a zwłaszcza państwach strefy euro, podjęcie reform w celu powołania stałego, antykryzysowego mechanizmu ratowania w potrzebie krajów

\footnotetext{
Ustawa z dnia 14 czerwca 1960 r. (tekst jedn. DzU 2000, Nr 98, poz. 1071 ze zm.). Ustawa z dnia 21 lipca 2006 r. (DzU nr 157, poz. 1119 ze zm.).

Na temat „,nowego podatku bankowego” zob. zwłaszcza P. Stanisławiszyn, op. cit., s. 140 i n. Co do Niemiec zob. M. Fedorowicz, op. cit., s. 77 i n.

18 Ideą leżącą u podstaw takiej regulacji jest chęć uniknięcia w przyszłości kapitalizowania banków z budżetu państwa. Analizowany problem w odniesieniu do Niemiec zob. ibidem, s. 82.
} 
strefy euro ${ }^{19}$ (co dało podstawy do podniesienia niezbędnego postulatu zmiany Traktatu Lizbońskiego) oraz utworzenia paktu na rzecz zwiększenia konkurencyjności euro, otwartego także dla krajów spoza Eurosystemu, zwanego „Paktem Euro Plus"20. Głównym celem Paktu jest zbliżanie narodowych polityk gospodarczych oraz ścisła koordynacja polityki zarządzania gospodarczego ${ }^{21}$. Okazuje się bowiem, że nie wystarcza już tylko integracja nadzoru finansowego na szczeblu UE. Istnieje również potrzeba zbliżania polityk gospodarczych UE tak w przypadku państw należących już do strefy wspólnej waluty euro, jak i objętych derogacją. Kryzys finansowy ujawnił nie tylko braki w krajowych systemach nadzorczych, ale i brak wspólnej efektywnej struktury nadzorczej na szczeblu UE, jak również braki w zakresie zbliżania polityk gospodarczych. Jeśli ESNF ma stanowić remedium na braki w strukturze nadzoru nad rynkiem finansowym w UE, to Pakt ma wspomóc koordynowanie polityk gospodarczych w UE. Pakt przewiduje koordynację $\mathrm{w}$ dziedzinie konkurencyjności, innowacji, zatrudnienia, ale również stabilności finansów publicznych oraz koordynacji podatkowej.

Wspomniano już, że podstawą dla konstrukcji podatku bankowego w polskim porządku prawnym miałaby stać się ustawa o podatku nakładanym na niektóre instytucje finansowe ${ }^{22}$. Zgodnie $\mathrm{z}$ rządowym projektem ustawy podatek ten

19 Przewiduje się, że Europejski Mechanizm Stabilizacyjny (EMS) zostanie wyposażony w 700 mld euro, w tym 500 mld euro ma być przeznaczone na pożyczki dla państw znajdujących się w kryzysie finansowym, a pozostała część ma być przeznaczona na zabezpieczenie najwyższej oceny kredytowej, http://www.european-council.europa.eu/home-page/highlights/deal-on-reinforced-economic-governance.aspx?lang=pl (4.4.2011). Zob. również Konkluzje Rady Europejskiej z dnia 25.3.2011 r., EUCO 10/11, CO EUR6, CONCL 3.

20 Pakiet został przyjęty w nocy 24/25 marca 2011 r. podczas szczytu Rady Europejskiej w Brukseli. Warto podkreślić, że Polska, obok Danii, Litwy, Łotwy, Rumunii i Bułgarii jest państwem, które mimo że nie należy jeszcze do III etapu UGiW, przystąpiło do paktu na rzecz konkurencyjności i obrony euro. Zob. Konkluzje Rady Europejskiej, s. 13 i n.

${ }_{21}$ Stanowi to zapowiedź realizacji dokumentów Komisji Europejskiej „Europa 2020”, w którym zapisano: „Kryzys doprowadził do zwiększenia wyzwań stojących przed strefą euro: stabilności finansów publicznych i potencjalnego wzrostu, destabilizującej roli nierównowagi budżetowej i różnic w konkurencyjności. [...]. Pilne sprostanie tym wyzwaniom w strefie euro ma ogromne znaczenie dla zagwarantowania stabilności oraz zrównoważonego rozwoju sprzyjającego zwiększeniu zatrudnienia. Wymaga to silniejszej koordynacji prowadzonej polityki, w tym: ram prawnych dla dokładniejszego i szerszego nadzoru nad państwami strefy euro: oprócz poprawienia dyscypliny budżetowej, nadzorem gospodarczym należy również objąć nierównowagę makroekonomiczną i rozwój konkurencyjności, w szczególności w celu ułatwienia dostosowań wynikających z prowadzonej polityki; ram prawnych umożliwiających działanie w obliczu zbliżających się zagrożeń stabilności finansowej strefy euro jako całości; odpowiedniej reprezentacji strefy euro na zewnątrz, która umożliwi zdecydowane działania w obliczu światowych wyzwań gospodarczych i finansowych”, zob. Komunikat Komisji Europejskiej „Europa 2020 - Strategia na rzecz inteligentnego i zrównoważonego rozwoju sprzyjającego włączeniu społecznemu” z dnia 3.3.2010 r., KOM (2010) 2020 wersja ostateczna, s. 30 i 31.

${ }_{22}$ Zob. druk sejmowy $\mathrm{nr} 3838 \mathrm{z}$ dnia 7.9.2010 r. zawierający poselski projekt ustawy o podatku od niektórych instytucji finansowych. W chwili oddania artykułu do druku rządowy projekt 
nie miałby wpływać do budżetu państwa, a na specjalny fundusz utworzony przy Bankowym Funduszu Gwarancyjnym i służyłby, w razie wystąpienia sytuacji kryzysowej, dokapitalizowaniu banków. Warto zauważyć, że z formalnego punktu widzenia wskazane obciążenie finansowe nie stanowiłoby podatku, a raczej opłatę ostrożnościową. Szacuje się, że wpływy z tego tytułu będą porównywalne do wielkości środków przekazywanych przez banki do BFG ${ }^{23}$. Podstawą do naliczania opłaty miałaby stać się wielkość pasywów pomniejszona o wysokość funduszy podstawowych oraz suma środków gwarantowanych przez BFG. Ponadto opłata ta miałaby być również uzależniona od wielkości gwarantowanych depozytów. Regulacja miałaby hołdować zależności zakładającej pomniejszenie opłaty w sytuacji, w której im więcej znajdzie się w bilansie gwarantowanych depozytów, tym mniejsza będzie wielkość wymaganej opłaty. Warto zauważyć, że opłaty pobierane od banków i niektórych innych instytucji finansowych (np. Skoków) mogą powodować zmniejszenie działalności kredytowej banków, a tym samym wpływać hamująco na rozwój gospodarki. $Z$ drugiej strony zabezpieczenie stabilności sektora finansowego, dyskutowane obecnie w płaszczyźnie prawa UE, może dokonać się również przez utworzenie szczególnego funduszu restrukturyzacyjnego finansowanego $\mathrm{z}$ dodatkowych zobowiązań nałożonych na sektor finansowy ${ }^{24}$.

Kolejnym nowym instrumentem antykryzysowym uregulowanym w aktach UE powołujących ESNF są procedury naprawcze. Zgodnie z art. 25 rozporządzenia o EBA Urząd przyczynia się do opracowywania i koordynowania skutecznych i spójnych planów naprawczych, procedur mających zastosowanie w sytuacjach nadzwyczajnych i środków zapobiegawczych służących zminimalizowaniu systemowego znaczenia wszelkich przypadków upadłości ${ }^{25}$. Na urząd ten nałożo-

ustawy nie był jeszcze dostępny na stronach internetowych Sejmu RP. W poselskim projekcie przewiduje się opodatkowanie aktywów niektórych instytucji finansowych (banków krajowych, oddziałów banków zagranicznych, oddziałów instytucji kredytowych, krajowych zakładów ubezpieczeń, krajowych zakładów reasekuracji, oddziałów zagranicznych zakładów ubezpieczeń i zagranicznych zakładów reasekuracji, głównych oddziałów zagranicznych zakładów ubezpieczeń i zagranicznych zakładów reasekuracji oraz funduszy inwestycyjnych. Warto podkreślić brak Skoków jako podmiotów objętych zakresem podmiotowym tym podatkiem. Podstawą opodatkowania tym podatkiem miałyby stać się aktywa (w projekcie nieprecyzyjnie użyty zwrot „suma aktywów”) instytucji finansowych, co może stanowić obciążenie dla działalności kredytowej banków i podrożenie kosztów uzyskania kredytu. Podatek ten, w założeniu projektodawców, miałby stanowić wpływ do budżetu państwa.

23 Wypowiedź min. D. Daniluka podczas XVII Forum Bankowego, 10 marca 2011 r., Warszawa.

24 Zob. np. stanowisko Rady Ministrów z dnia 1 marca 2011 r. dotyczące poselskiego projektu ustawy o podatku od niektórych instytucji finansowych (druk nr 3838), s. 2 i n.

25 Odpowiedniki wskazanego artykułu znajdują się w art. 25 rozporządzenia o EIOPA i art. 25 rozporządzenia o ESMA. 
no obowiązek aktywnego uczestnictwa w tych działaniach. Dla realizacji tego celu EBA może określać najlepsze praktyki mające ułatwiać przeprowadzanie postępowań naprawczych wobec upadających instytucji, a w szczególności grup transgranicznych. Celem tego unormowania jest zapobieganie rozprzestrzenianiu się zjawiska upadłości, zapewnianie dostępu odpowiednich narzędzi, w tym wystarczających zasobów, i możliwość przeprowadzenia postępowania naprawczego w danej instytucji lub grupie w sposób uporządkowany, oszczędny i terminowy. EBA może opracować projekty regulacyjnych i wykonawczych standardów technicznych dotyczących procedur naprawczych.

Do antykryzysowych instrumentów sensu largo zaliczyć trzeba również unormowania dotyczące europejskiego systemu gwarantowania depozytów. Zgodnie $z$ art. 26 rozporządzenia o EBA Urząd przyczynia się do wzmocnienia europejskiego systemu obejmującego krajowe systemy gwarantowania depozytów w celu zapewnienia poprawnego stosowania dyrektywy 94/19/WE. Chodzi bowiem o zapewnienie odpowiedniego finansowania krajowych systemów gwarantowania depozytów ze składek uiszczanych przez instytucje finansowe, w tym instytucje finansowe utworzone i przyjmujące depozyty w UE, ale mające siedziby poza Unią, jak określono w dyrektywie 94/19/WE, i w celu zapewnienia wysokiego poziomu ochrony wszystkim deponentom w zharmonizowany sposób w całej Unii, co nie narusza stabilizacyjnej ochronnej roli wzajemnych systemów gwarancyjnych, pod warunkiem że są one zgodne z przepisami unijnymi. W tym celu EBA może przyjmować wytyczne i zalecenia oraz opracowywać regulacyjne i wykonawcze standardy techniczne ${ }^{26}$.

Odrębną regulację przewidziano w ramach europejskiego systemu postępowania naprawczego wobec banków i ustaleń dotyczących finansowania. Zgodnie z art. 27 rozporządzenia o EBA Urząd ten może bowiem uczestniczyć w opracowywaniu metod prowadzenia postępowania naprawczego wobec upadających instytucji finansowych ${ }^{27}$. Chodzi tu zwłaszcza o instytucje, które mogą stwarzać

26 W art. 26 rozporządzenia o EIOPA uregulowano, że Urząd może przyczyniać się do oszacowania potrzeby ustanowienia europejskiej sieci krajowych ubezpieczeniowych programów gwarancyjnych, która byłaby odpowiednio finansowana i wystarczająco zharmonizowana. Z kolei w art. 26 rozporządzenia o ESMA wskazano, że Urząd przyczynia się do umocnienia europejskiego systemu obejmującego krajowe systemy rekompensat dla inwestorów (ICS), działając na mocy uprawnień powierzonych mu $\mathrm{w}$ niniejszym rozporządzeniu, aby zapewnić prawidłowe stosowanie dyrektywy 97/9/WE w celu zapewnienia odpowiedniego finansowania krajowych systemów rekompensat inwestorów ze składek zainteresowanych uczestników rynku finansowego, w tym, w stosownych przypadkach, uczestników rynków finansowych z siedzibą w krajach trzecich, i gwarantuje wysoki poziom ochrony na terytorium całej Unii wszystkim inwestorom za pomocą zharmonizowanych ram.

27 W art. 27 rozporządzenia o EIOPA unormowano, że Komisja może się zwrócić do Urzędu, by organ ten uczestniczył w ocenie, o której mowa w art. 242 dyrektywy 2009/138/WE, w szczególności w odniesieniu do współpracy między organami nadzoru w ramach kolegiów organów nad- 
ryzyko systemowe. Głównym założeniem tych postanowień jest zapobieganie rozprzestrzenianiu się tego zjawiska i umożliwienie zakończenia działalności przez te instytucje w sposób uporządkowany i terminowy. Ponadto EBA uczestniczy w ocenie konieczności stworzenia systemu spójnych, solidnych i wiarygodnych mechanizmów finansowania obejmujących odpowiednie instrumenty finansowe powiązane $z$ pakietem skoordynowanych krajowych planów w zakresie zarządzania w sytuacjach kryzysowych. Na EBA nałożono również obowiązek uczestnictwa w pracach nad kwestiami dotyczącymi równych warunków działania oraz nad łącznym wpływem na instytucje finansowe wszelkich systemów opłat i składek, które mogą być wprowadzone, by zapewnić równomierne rozłożenie obciążeń, jak również nad wpływem zachęt - służących ograniczaniu ryzyka systemowego - jako elementu spójnego i wiarygodnego programu naprawczego. W ramach przeglądu rozporządzenia ocenie ma podlegać potrzeba utworzenia europejskiego funduszu naprawczego.

Do instrumentów antykryzysowych sensu largo zaliczyć trzeba również rozwiązania przewidywane dyrektywą 2009/111/WE Parlamentu Europejskiego i Rady z dnia 16 września 2009 r. zmieniającą dyrektywy 2006/48/WE, 2006/49/ /WE i 2007/64/WE w odniesieniu do banków powiązanych z centralnymi instytucjami, niektórych pozycji funduszy własnych, dużych ekspozycji, uzgodnień w zakresie nadzoru oraz zarządzania w sytuacji kryzysowej (dyrektywa CRD II) ${ }^{28}$. Przepisy implementowanej dyrektywy CRD II mają na celu zwiększenie stabilności i bezpieczeństwa rynku finansowego ${ }^{29}$. Warto na marginesie zaznaczyć, że efektywne wdrożenie tej dyrektywy wymaga skoordynowania działań nadzorcy z bankiem centralnym, a także z właściwymi organami nadzoru państw człon-

zoru, a także do funkcjonalności tych kolegiów, do praktyk nadzorczych dotyczących ustanawiania narzutów kapitałowych, oceniania korzyści ze wzmocnienia nadzoru nad grupą i zarządzania kapitałem w grupie zakładów ubezpieczeń lub zakładów reasekuracji, w tym ewentualnych środków wzmocnienia należytego transgranicznego zarządzania grupami ubezpieczeniowymi, zwłaszcza w odniesieniu do zarządzania ryzykami i aktywami. Z uwzględnieniem specyfiki dotyczącej działań ESMA Urząd ten, zgodnie z art. 27 rozporządzenia o ESMA, w zakresie swoich kompetencji przyczynia się do opracowywania metod prowadzenia postępowania naprawczego wobec upadających kluczowych uczestników rynku finansowego, tak by zapobiec rozprzestrzenianiu się tego zjawiska, umożliwić zakończenie działalności przez tych uczestników w sposób uporządkowany i terminowy, a także - w stosownych przypadkach - wraz ze spójnymi i wiarygodnymi mechanizmami finansowania. Ponadto ESMA uczestniczy w pracach nad kwestiami dotyczącymi równych warunków działania oraz nad łącznym wpływem na instytucje finansowe wszelkich systemów opłat i składek, które mogą być wprowadzone, by zapewnić równomierne rozłożenie obciążeń, jak również nad wpływem zachęt - służących ograniczaniu ryzyka systemowego - jako elementu spójnego i wiarygodnego programu naprawczego.

28 Dz. Urz. UE L 302 z 17.11.2009 r., s. 97.

29 Ustawa z dnia 28 kwietnia 2011 r. o zmianie ustawy - Prawo bankowe, ustawy o obrocie instrumentami finansowymi oraz ustawy o nadzorze nad rynkiem finansowym (DzU Nr 131, poz. 763), tzw. ustawa implementująca CRD II. 
kowskich dla ograniczenia ryzyka systemowego dla sektora finansowego - w tym zagrożenia dla stabilności krajowego systemu finansowego ${ }^{30}$. Chodzi tu w szczególności o ustalenie obowiązku wymiany informacji pomiędzy Komisją Nadzoru Finansowego, Narodowym Bankiem Polskim, bankami centralnymi w innych państwach członkowskich, organami nadzoru w innych państwach członkowskich oraz innymi centralnymi organami administracji rządowej odpowiedzialnymi za ustawodawstwo dotyczące nadzorowania instytucji kredytowych, instytucji finansowych, usług inwestycyjnych i zakładów ubezpieczeń, w przypadku zaistnienia sytuacji nadzwyczajnych na rynkach finansowych. Dyrektywa ta zmienia przepisy dyrektyw CRD (2006/48/WE) i CAD (2006/49/WE), które ustanawiają wymogi adekwatności kapitałowej, mające zastosowanie do instytucji kredytowych i firm inwestycyjnych, określają zasady dotyczące obliczania funduszy własnych oraz zasady ich nadzoru ostrożnościowego. Przepisy ustawy implementującej CRD II przewidują w tym zakresie w odniesieniu do prawa bankowego doprecyzowanie definicji podmiotów powiązanych kapitałowo i organizacyjnie (art. 1 pkt 1). Państwa członkowskie zobowiązano, aby przy określaniu, czy grupy klientów można uznać za powiązane, a zarazem czy zbiór ekspozycji wobec klientów generuje wspólne ryzyko, brać pod uwagę również ryzyko wynikające z faktu korzystania $z$ tego samego źródła znaczącego finansowania. Kolejną zmianą wynikającą z wdrożenia dyrektywy CRD II jest modyfikacja art. 71 ustawy - Prawo bankowe ${ }^{31}$. Chodzi w tym przypadku o dalsze ograniczanie ryzyka kredytowego i operacyjnego, zwiększenie stabilności finansowej i ochronę klientów. Zgodnie z przepisami dyrektywy CRD II zaangażowania wobec banków krajowych, banków zagranicznych oraz instytucji kredytowych, jak również wobec podmiotów powiązanych kapitałowo lub organizacyjnie składających się z ww. podmiotów nie mogą przekraczać wyższej z następujących kwot: 25\% funduszy własnych lub 150 mln euro, pod warunkiem że suma zaangażowań, z uwzględnieniem technik ograniczania ryzyka kredytowego, wobec wszystkich powiązanych podmiotów, które nie są bankiem krajowym, instytucją kredytową lub bankiem zagranicznym, nie przekracza $25 \%$ funduszy własnych banku. Państwa członkowskie mogą jednak ustalić limit niższy niż $150 \mathrm{mln}$ euro, o czym zobowiązane są poinformować Komisję Europejską. Dokonując implementacji, polski ustawodawca nie skorzystał z możliwości art. 111 ust. 1 dyrektywy CRD i nie ustalił niższego limitu (art. 1 pkt 5 ustawy implementującej CRD II). Ponadto dla celów efektywnego sprawowania nadzoru nad sektorem bankowym oraz ograniczenia uznaniowości przy określaniu limitu przez banki wprowadzono dodatkowy wymóg w postaci

30 Zob. uzasadnienie do druku sejmowego nr 3974, który zawierał rządowy projekt ustawy z 14.3.2011 r. o zmianie ustawy - Prawo bankowe, ustawy o obrocie instrumentami finansowymi oraz ustawy o nadzorze nad rynkiem finansowym (obowiązującej ustawy implementującej CRD II).

31 Zob. art. 1 pkt 5 ustawy implementującej CRD II. 
konieczności ustalania corocznego limitu przez przedsiębiorstwa bankowe oraz informowania o jego wysokości nadzorcy. $Z$ kolei dla zapewnienia niezbędnego przepływu informacji dla banku ustanowiono obowiązek przekazywania na żądanie właściwej władzy nadzorczej, sprawującej nadzór skonsolidowany nad tym bankiem, informacji objętych tajemnicą bankową, aby umożliwić właściwe sprawowanie nadzoru skonsolidowanego przez nadzorców z państw członkowskich, a także przez nadzorców z państw trzecich, jeśli zostanie zawarte odpowiednie porozumienie pomiędzy tym nadzorcą a Komisją Nadzoru Finansowego ${ }^{32}$. Szczególnie cennym, implementowanym postanowieniem dyrektywy CRD II jest określenie obszaru i zasad współpracy pomiędzy właściwymi władzami nadzorczymi a Komisją Nadzoru Finansowego, w ramach sprawowanego nadzoru skonsolidowanego, w zakresie stosowania środków nadzorczych ${ }^{33}$. Implementacja CRD II stała się zatem istotna z punktu widzenia zapewnienia stabilności systemowi finansowemu i zwiększenia ochrony instytucji finansowych na rynku, a regulacje z zakresu wymogów kapitałowych wpisują się bezpośrednio w mechanizm ochrony rynku finansowego przed kryzysami.

Regulacją należącą do systemu instrumentów antykryzysowych sensu largo jest unormowanie dotyczące gwarantowanych wypłat deponentom w sytuacji upadłości banku ${ }^{34}$. Na mocy ustawy z 16.12.2010 r. o zmianie ustawy o BFG i niektórych innych ustaw podniesiono gwarantowane wypłaty deponentom do wysokości równowartości w złotych kwoty 100000 euro w 100\% (wcześniej 50000 euro w 100\%), co stanowi znaczące wsparcie i ochronę dla klientów banków w razie upadłości banków ${ }^{35}$.

\section{ZAKOŃCZENIE}

Analizowana regulacja, w tym w szczególności przybliżone unormowania instrumentów antykryzysowych, pozwalają sformułować wniosek, że w dobie globalizacji rynków finansowych nieodzowna wydaje się integracja instrumentów walki z kryzysem finansowym na szczeblu europejskim. Wyrazem tej tendencji jest nie tylko regulacja nowego europejskiego nadzoru finansowego, ale również dyskusje

32 Zob. regulację art. 105 ust. 1 pkt 2 lit. q ustawy - Prawo bankowe zawartą w ustawie implementującej CRD II (art. 1 pkt 6).

33 Zob. regulację art. 138b ustawy - Prawo bankowe zawartą w ustawie implementującej CRD II (art. 1 pkt 12).

34 Dyrektywa Parlamentu Europejskiego i Rady 2009/14/WE z 11 marca 2009 r. zmieniająca dyrektywę 94/19/WE w sprawie systemów gwarantowania depozytów w odniesieniu do poziomu gwarancji oraz terminu wypłaty (Dz. Urz. UE L 68 z 13.03.2009 r., s. 3).

35 DzU Nr 257, poz. 1724. 
wokół unormowań dotyczących Bazylejskiego Komitetu Nadzoru Bankowego, Międzynarodowej Organizacji Komisji Papierów Wartościowych oraz Międzynarodowego Stowarzyszenia Nadzorów Ubezpieczeniowych, związane ze sposobem wdrażania nadzorczych zaleceń i wytycznych uchwalanych przez te gremia ${ }^{36}$.

$\mathrm{Z}$ formalnoprawnego punktu widzenia nastąpiła niewątpliwa integracja instrumentów antykryzysowych, zarówno tych sygnalizujących ostrzeżenia, jak i ingerujących w rynek. Natomiast $z$ materialnoprawnego punktu widzenia pojawiają się już pierwsze wątpliwości. Chodzi zwłaszcza o tzw. stress test dla banków przeprowadzany obecnie przez EBA. Okazuje się bowiem, że test ten jest łagodniejszy niż dotychczasowe stosowane przez nadzory krajowe. Jeśli wytyczne i zalecenia EBA czy pozostałych ESA będą wprowadzały standardy nadzorcze niższe od wymaganych już obecnie przez nadzorców finansowych, to pogorszy to efektywność krajowego nadzoru finansowego. Jeśli natomiast standardy te zostaną zaostrzone w porównaniu do obecnie obowiązujących w państwach członkowskich, to można rozważać, by zacząć je wpisywać do prawodawstwa krajowego, po to, aby uzyskały charakter wiążący.

Wydaje się, że dopiero suma instrumentów antykryzysowych sensu stricto i sensu largo pomoże stworzyć fundament służący bezpieczeństwu finansowemu w razie wystąpienia kolejnego kryzysu ${ }^{37}$. Nie wszystkie jednak instrumenty można uznać za potrzebne, a efektywność niektórych z nich uzależniona jest od stworzenia regulacji, których celem byłoby wymuszenie szybkości, pewności i gwarancji przepływu informacji rynkowej. Podatek bankowy nie wydaje się optymalnym rozwiązaniem i może spowodować podrożenie kosztów uzyskania kredytu oraz obsługi bankowej.

Wprowadzenie regulacji integracji nadzoru nad rynkiem finansowym w UE nie wydaje się już wystarczające. Niezbędne staje się zwłaszcza zreformowanie gospodarek państw UE, w tym szczególnie państw strefy euro. Stanowi to zresztą jeden z celów Strategii „Europa 2020”. Trzeba bowiem koniecznie podkreślić, że $\mathrm{w}$ istocie UE boryka się obecnie z kryzysem finansowym, który miał dwie niezależne podstawy. $Z$ jednej strony chodziło o kryzys wywołany błędną polityką kredytową banków hipotecznych w Stanach Zjednoczonych i wadliwą działalnością agencji ratingowych, czyli pełnym luk systemem nadzoru finansowego w UE,

\footnotetext{
36 G. Bertolozzo, op. cit., s. 264 i n.

37 Taki jest zamysł europejskiego prawodawcy, gdyż w Strategii „Europa 2020” wskazano, że celami cząstkowymi służącymi Strategii mają być: realizacja reform nadzoru finansowego, promowanie przejrzystości, stabilności i odpowiedzialności za działania, w szczególności w odniesieniu do instrumentów pochodnych i infrastruktury rynkowej, wzmocnienie zasad ostrożnosciowych, wzmocnienie zasad zarządzania instytucjami finansowymi, przeprowadzenie konsolidacji budżetowej na rzecz długotrwałego wzrostu, koordynacja gospodarcza w ramach UGiW. Szerzej zob. Komunikat Komisji Europejskiej „Europa 2020 - Strategia na rzecz”, s. 29.
} 
$\mathrm{z}$ drugiej strony natomiast nadal realne są ryzyka występujące $\mathrm{w}$ gospodarkach państw strefy euro. Wskazane źródła problemów finansowych w UE wymagają zatem kompleksowych, systemowych i spójnych rozwiązań i regulacji. Wydaje się, że wprowadzenie zespołu instrumentów antykryzysowych sensu largo pozwoli na systemową analizę sytuacji kryzysowych i znalezienie najbardziej efektywnych instrumentów przeciwdziałania kryzysom finansowym.

\section{BIBLIOGRAFIA}

Arora A., The Global Financial Crisis: A New Global Regulatory Order?, „, The Journal of Business Law" 2010, No. 8.

Arora A., The 2007-2009 banking crisis and the EU's regulatory response, „European Business Law Review" 2010, vol. 21, No. 5.

Bertolozzo G., The European Union facing the global arena: standard-setting bodies and $f-$ nancial regulation, „European Law Review” 2009, vol. 34, No. 2.

Denning U., Zunehmende Konzentration der europäischen Finanzaufsicht, „Wirtschaftsdienst" 2001, vol. 81, Nr. 10.

Fedorowicz M., Normatywne aspekty regulacji europejskiego nadzoru finansowego ze szczególnym uwzględnieniem europejskiego nadzoru w prawie bankowym, [w:] System finansów publicznych. Prawo finansowe wobec wyzwań XXI wieku, red. A. Dobaczewska, E. Juchniewicz, T. Sowiński, wyd. I, Warszawa 2010.

Fedorowicz M., Podstawowe zatożenia niemieckiego pakietu ustaw o stabilizacji rynku finansowego z dnia 17.10.2008 r., „EuroEkspert”2009, nr 1.

Hofmann G., Neue Finanzarchitektur, Reform der Aufsichtsregeln und Aufsichtspraktiken in Europa: Sind wir auf dem richtigen Weg?, „Kreditwesen“ 2010, Nr. 13.

Iwanicz-Drozdowska M., Bazylea II i wyptacalność - szanse i wyzwania, [w:] Bankowość, red. J. Węcławski, Lublin 2006.

Jurkowska-Zeidler A., Nowe europejskie ramy ocbrony stabilności wewnętrznego rynku finansowego, [w:] System finansów publicznych. Prawo finansowe wobec wyzwań XXI wieku, red. A. Dobaczewska, E. Juchniewicz, T. Sowiński, wyd. I, Warszawa 2010.

Lamandini M., When More is Needed: The European Financial Supervisory Reform and Its Legal Basis, „European Company Law” 2009, vol. 6, No. 5.

Lehmann M., Manger-Nestler C., Die Vorschläge zur neuen Architektur der europäischen Finanzaufsicht, „Europäische Zeitschrift für Wirtschaftsrecht” 2010, Nr. 3.

Marcinkowska K., Kręte ścieżki Bazylei..., czyli standardy kapitatowe banków: wczoraj, dzis i jutro, „Annales Universitatis Mariae Curie-Skłodowska”, Lublin-Polonia 2010, XLIV, 2, Sectio H.

Masciandaro D., Regulating the Regulators: The Changing Face of Financial Supervision Architectures before and after the Crisis, „European Company Law” 2009, vol. 6, No. 5.

Michór A., Nowa europejska architektura nadzoru nad rynkiem bankowym, „Bezpieczny Bank" 2011, nr 1. 
Pohl W., Innovative Finanzinstrumente im gemeinsamen Europäischen Bankenmarkt, Baden-Baden 1994.

Rutkowska-Tomaszewska E., Zasady racjonalnego zarzadzania ryzykiem plynności banków w zaleceniach Komitetu Bazylejskiego, [w:] Wyzwania regulacyjne wobec doświadczen globalnego kryzysu finansowego, red. J. Szambelańczyk, Warszawa 2011.

Schmitz A., Finanzmarktkrise und Reorganisation von Banken, „Zeitschrift für Wirtschaftsrecht" 2010, Heft 24.

Stanisławiszyn P., Perspektywy zmian europejskich regulacji w zakresie nadzoru finansowego w 2011 r., [w:] Wyzwania regulacyjne wobec doświadczeń globalnego kryzysu finansowego, red. J. Szambelańczyk, Warszawa 2011.

Zombirt J., Nowa umowa kapitatowa erwolucja czy rewolucja, Warszawa 2007.

\section{REGULATION OF FINANCIAL MARKET SUPERVISION IN THE EU - INTEGRATION OR DISINTEGRATION OF THE LEGAL ANTI-CRISIS INSTRUMENTS} SUMMARY

The article discussed the problem of the new instruments of financial supervision within the European Union. The legal instruments were analyzed and grouped in legal anti-crisis instruments sensu stricto and legal anti-crisis instruments sensu largo. The new anti-crisis instruments and their legal regulations were defined, analyzed, evaluated, and attached to globalization processes on the financial market. 
